\title{
Effect of Osmotic Dehydration as Apre-treatment on some Characteristics of Ventilated Hot Air Drying (VHD) Kiwifruit Slices
}

\section{Mohamed Bassim Atta and Hagar Fathy Kandil}

Food Science and Technology Department, Faculty of Agriculture, Tanta University, Egypt

Received on: 20/12/2016

Accepted for publication on: 22/12/2016

\begin{abstract}
Food dehydration of fruits is one of the most challenging processes in food technology. In order to optimize the quality of dehydrated fruits novel dry conservation procedures should be developed. Where ventilated hot air dryers'(VHD) produces poor fruit quality. So, different methods were applied to decrease the drawbacks of traditional methods. Kiwifruit slices submitted to steaming and osmotic dehydration (OD) in $60 \%$ sucrose solution as pre-treatment followed by VHD was studied. Results revealed that weight reduction (WR), water loss (WL) and solid gain (SG) of kiwifruit were significantly increased as extend of immersion period. Weight reduction (WR) was found to be lower than water loss (WL) during OD. On the other hand, WL was higher than that of SG. Steaming and/or OD as pre-treatment for kiwifruit drying increases the membrane permeability. Moreover, steaming process releases the trapped air from the kiwifruit tissue. Thus increase both water loss (WL) and dehydration efficiency index (DEI). Contrary, decrease moisture content (MC) in the final product. Steaming process is more pronouncing effect than that of OD. Rehydration capacity (RC) of dried kiwifruit slices improves by OD using osmotic solution (60\% sucrose) at $40^{\circ} \mathrm{C}$ for $2 \mathrm{hrsas}$ pre-treatment while steaming process has no remarkable effect.
\end{abstract}

Keywords: Kiwifruit slices, Osmotic dehydration, Water loss, Solid gain, Dehydration efficiency index, Rehydration capacity.

\section{Introduction}

Kiwifruit (Actinidiadeliciosa) is popularand widespread fruit belongs to Actinidiaceae family (Ferguson, 1990). The estimated world production is about 1.4 million metric tons per year, where Italy becoming the first producer country which produced $30 \%$ of the total world production (FAO, 2010). It is a highly nutritional fruit due to its high level of vitamin $\mathrm{C}$ and its strong antioxidant capacity because of a wide number of phytonutrients including carotenoids, lutein, phenolics, flavonoids, and chlorophyll (Cassano, et al., 2006). On the other hand, ki- wifruit has a very short shelf-life due to its high moisture content which fluctuates between 80 - 86\% (Fathi, et al., 2011a; Hosseinzadeh, et al., 2013). Therefore it is necessary to dry the fruit to increase its shelf life at room temperature without deteriorations, reduction in weight and volume thereby minimize the cost of packaging, handling and transportation during storage orexport (Maskan, 2001; Senadeera, et al., 2005; Diamante, et al., 2010). Dried kiwifruits can be eaten as a snack or added to cereals, decorate desserts and ice cream (Etsey, et al., 2007; Reynolds, 2007; Chin, et al., 2015). 
Osmotic dehydration (OD) is a technique used for different fruits including kiwifruit as a pre-treatment to many preservation processes such as freezing, ohmic heating, microwave, and hot air drying (Robbers, et al., 1997; Allaeddini and EmamDjomeh, 2004; Fathi, et al., 2011b) to reduce the initial water content, energy consumption and total drying time (Escriche, et al., 2000b; Gianotti, et al., 2001; Bekele and Ramaswamy, 2010). At the same time, improves sensory, functional and nutritional properties including vitamins, phytochemicals and microelements of dried product without changing their integrity (Moreira and sereno, 2003; Sun, 2005; Osorio, et al., 2007; Fathi, et al., 2011a). So, $\mathrm{OD}$ is an effective technique to use for the partial removal of water from plant tissues by immersion in a hypertonic (osmotic) solution (Cao, et al., 2006). Water removal is based on the natural and non-destructive phenomenon of osmosis across cell membranes. The diffusion of water out of the plant's tissues is accompanied by the simultaneous counter diffusion of solutes from the osmotic solution into the tissue. There may also be minor flow of other solutes from fruit to the solution (Torreggiani and Bertolo, 2001; Shi and xue, 2009). The OD is usually performed under ambient or modified environment conditions (Escriche, et al., 2000a; Cao, et al., 2006; Fazliand Ahani, 2010; Fasogbon, et al., 2013).Conventional ventilated hot air drying (VHD) of fruit including kiwifruits leads to some disadvantages in the final products such as loss of volatiles and flavours, dark colour, leathery texture, shrinkage, decrease the rehydration rate, wettability, surface hardening and may decrease the nutritional value (Maskan, 2000; Singh, et al., 2008b; Chin, et al., 2015). Therefore OD could be applied to produce readyto-eat dry foods or treated as secondary raw material to avoid the aforementioned drawbacks (Menges and Ertekin, 2006; Phisut, 2012). Because of cell membrane is semipermeable permit water and acid to pass through more rapidly than sugar, therefore water and acid of fruit are flow out from the cell at first fast and then move slowly. Contrary to sugar which is penetrate the cell gradually and increases with prolonging immersion time. Therefore, the characteristics of the product and prompt of processing can be varied by controlling temperature, concentration of osmosis solution and time (Chavan, 2012). As a result, considerable amounts in the mass exchange can influence the final nutritive values and organoleptic properties of the dried food. Analogous, cellular membrane of fresh kiwifruit slices exerts high resistances to mass transfer and slows down the rate of OD (Erule and Shubert, 2001). Thus, a number of techniques include blanching, freezing, high pressure, ohmic heating, pulsed electric field and ultrasound have been tried to improve mass transfer rate during OD (Amami, et al., 2006; Allali, et al., 2010; Bchir, et al., 2011). Blanching is one of the most widely used pre-treatments in the drying because of the resultant inactivation of enzymes, changes in tissue structure and shorter drying time (Latapi and 
Barrett, 2006; Lewicki, 2006). The same results were achieved with blanched or steamed kiwifruit slices (Nadian, et al., 2016; Llanoa, et al., 2003). Rehydration of dried foods is a complex practice influenced by several factors such as chemical composition, physical structure, drying techniques, temperature of drying, conditions and composition of the immersion medium (KaymakErtekin, 2002; Taiwo and Adeyemi, 2009) which play a major role on the quality attributes of the product. In this respect Maskan (2001) stated that dried kiwifruit slices by VHD pre-treated with microwave exhibited higher rehydration capacity and faster water absorption rate than those dried with microwave or VHD only. This work was carried out to investigate the influence of OD and/or steaming as pre-treatment on the dried kiwifruit slices characteristics using VHD including water loss (WL), weight reduction (WR) and solid gain (SG) during OD. Also moisture content (MC), mass loss (ML) of dried kiwifruit slices and their rehydration capacity (RC) were studied.

\section{Materials and Methods}

\subsection{Materials}

Fresh under ripe, free from physical defected, kiwifruits (Actinidia deliciousvar. Hayward) hadrefractive index $12.5^{\circ}$ Brix and commercial sucrose were obtained from the local market of Tanta City, ELGharbia Governorate, Egypt, in the year 2014. The fruits were transferred to the Laboratory of Food Science and Technology Department, Faculty of Agriculture, Tanta University.

\subsection{Methods}

\subsubsection{Sample preparation}

Kiwifruits were washed under the tap water, sorted manually and drained using clean cloth. The fruits were divided randomly into 4 groups $3000 \mathrm{~g}$ each. The fruits were peeled with sharp knife. Then the peeled fruits were cut into slices transversally to their axis (about $10 \mathrm{~mm}$ thickness cross sections to get equal size as much as possible and $40 \mathrm{~mm}$ diameter) by an electric cutting machine (Privileg Art. Nr. 273.0513, Germany). The surface of slices was dried gently by using tissue papers before measuring their dimensions and initial weight. Drying was performed in a laboratory using VHD at air velocity of $1.0 \mathrm{~m} / \mathrm{s}$. Before each drying experiment, the drier was run without sample for about $30 \mathrm{~min}$ to set desired temperature.

\subsubsection{Drying process:}

1.2.2.1. Ventilated hotairoven drying (VHD)

The $1^{\text {st }}$ group was dried by directly loaded onto stainless steel trays and subjected to drying using VHD at 50[ C for 3 and $6 \mathrm{hrs}$ at air velocity $1.0 \mathrm{~m} / \mathrm{s}$. This represents control (C). The $2^{\text {nd }}$ group was steamed at atmospheric pressure $(100 \square \mathrm{C})$ for 5 min till inhibit peroxidases, immersed in an ice-water bath to stop heating and drained on tissue papers. The steamed sample was loaded onto stainless steel trays and subjected to drying using (VHD) at 500 $\mathrm{C}$ for 3 and $6 \mathrm{hrs}$ at air velocity $1.0 \mathrm{~m} / \mathrm{s}$. This represents treatment no. 1(T1).

\subsubsection{Drying of kiwifruit slices by combination of $O D$ and VHD}


The $3^{\text {rd }}$ group of kiwifruit slices were immerged in osmotic solution (60 $\square$ Brix sucrose) at fruit to solution ratio $(1: 4 \mathrm{w} / \mathrm{v})$ to avoid changes in the solution concentration at $40 \square \mathrm{C}$ with occasionally shaking at $150 \mathrm{rpm}$ for $2 \mathrm{hrs}$. The slices were removed from osmotic solution and gently blotted with tissue paper followed by drying using VHD at $50 \square \mathrm{C}$ with air velocity at $1.0 \mathrm{~m} / \mathrm{s}$ for 3 and $6 \mathrm{hrs}$. This represents treatment no. 2 (T2). The $4^{\text {th }}$ group of kiwifruit slices were steamed at atmospheric pressure $(100 \square \mathrm{C})$ for 5 min till inhibit peroxidases and immersed in an icewater bath to stop heating, drained on tissue papers, subjected to OD as described earlier and then dried by using VHD at $50 \square \mathrm{C}$ with air velocity at $1.0 \mathrm{~m} / \mathrm{s}$ for 3 and $6 \mathrm{hrs}$. This step represents treatment no. 3 (T3).

\subsubsection{Determination of mois- ture content (MC)}

Moisture content (MC) using an electric oven at $105 \pm 5^{\circ} \mathrm{C}$ until constant weight (method no. 952.4) of sample was carried out according to AOAC (2003).

\subsubsection{Determination of mass loss (ML) \\ Mass loss (ML) of dried kiwi-} fruit sample was determined using the following equations:

$$
\mathrm{ML}=\frac{\mathrm{mo}-\mathrm{m}}{\mathrm{mo}} \times 100
$$

Where:

$\mathrm{m}_{0}$ Initialmass of sample $\mathrm{m}$ Mass of sample after drying

\section{transfer during OD}

\subsubsection{Determination of mass}

Mass transfer including solid gain (SG), weight reduction (WR) and water loss (WL) were determined according to (Mavroudis, et al., 1998). While dehydration effi- ciency index (DEI) was determined as mentioned by (Tylewicz, et al., 2010) using the following equations:

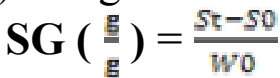

$$
\begin{aligned}
& \text { WR }\left(\frac{\underline{g}}{a g}\right)=\frac{W_{0}-w_{s}}{w_{0}} \\
& \text { WL ( } \\
& \text { DEI }=\mathrm{WL} / \mathrm{SG}
\end{aligned}
$$

Where:

$\mathrm{W}_{0}=$ Initial weight of sample $(\mathrm{g}), \mathrm{W}_{\mathrm{t}}=$ sample weight after treatment $(\mathrm{g})$

$\mathrm{S}_{0}=$ Initial solids content $(\mathrm{g})$,

$\mathrm{S}_{\mathrm{t}}=$ Total solid after treatment

(g)

\subsubsection{Determination of Re- hydration Capacity (RC)}

Rehydration capacity of dried kiwifruit sliceswas determined as described by Abano and Sam-Amoah, (2011) with slight modification as follows: About $5 \mathrm{~g}$ of the dried sample was placed in glass beakers containing distilled water in a ratio of $1: 30(\mathrm{w} / \mathrm{v})$ at room temperature for $15,30,45$ and $60 \mathrm{~min}$. Sample was removed and blotted with the paper towels in order to eliminate the surface water then weighed. The mass of rehydrated and dried samples were measured by using an accurate electronic balance (Radwag Wagi, Elcktroniczne, Model WTB 200, Poland) to the third digital number. The rehydration capacity (RC) described as weight of water gained during rehydration to weight of water removed during drying and calculated according to (Lewicki,1998) as following equations:

$$
\mathbf{R C}=\frac{W r-W d}{W-W d} \times 100
$$

Where:

$$
\mathrm{W}_{\mathrm{d}}=\text { weight of dried sample }(\mathrm{g})
$$



(g).

$\mathrm{W}_{\mathrm{r}}=$ weight of rehydrated sample

$\mathrm{W}=$ initial weight of sample $(\mathrm{g})$.

\subsection{Statistical Analyses}

Results tabulated in this work are means and standard deviation of at least three successfully trails. Then the data were statistically analysed using Analysis of Variance (ANOVA) and means were separated by Duncan's at a probability level of $0.05 \%$ (SAS, 2004).

\section{Result and Discussion}

2.1. Effect of steaming process on osmotic dehydration of kiwifruit slices

Weight reduction (WR) of kiwifruit slices immerged in osmotic sucrose solution (OS) $60^{\square}$ Brix is $0.227 \mathrm{~g} / \mathrm{g}$ after $1 \mathrm{hrs}$ at $40^{\circ} \mathrm{C}$, which increases to $0.349 \mathrm{~g} / \mathrm{g}$ when the immerging time is extend to $2 \mathrm{hrs}$. This attributed to increase contact time of the sample with the OS, which gives a higher moisture loss due to increase in osmotic pressure, thereby increase WR (Nieuwenhuijzen, et al., 2001). This result is disagreement with (Tylewicz, et al.,2010) who reported that OD using 61.5\% as OS for $2 \mathrm{hrs}$ led to $32 \% \mathrm{WR}$ of dried Hayward kiwifruit slices. This could be attributed to different handling process and sucrose concentration of OS. By analogous, water loss (WL) and solid gain (SG) of kiwifruit slices increases as a result of extends the soaking time in the OS. It is noticed that WR of dried kiwifruit slices is significantly lower than that of WL, however WL is higher than SG along all experiments as the time is extend. These results could be explained by water and soluble compounds leach out from kiwifruit tissue to the OS faster than that the uptake of sugar and solutes from the OS during OD (Fito, et al., 2001; Marani, et al., 2007; Tortoe, 2010). Because of the cell membranes are semi-permeable natures they allow water and low molecules size to pass by a greater driving forcethrough them more rapidly than sucrose. Therefore water is removed at first and then moves slowly, while sugar penetration is very slight at first but increases with the time (Tylewicz, et al., 2010; Chavan, 2012).

Table 1. Effect of steaming process on osmotic characteristics inkiwifruit (Actinidiadeliciasa var. Hayward) slices during $\mathrm{OD}$ at $40^{\circ} \mathrm{C}$

\begin{tabular}{|l|c|c|c|c|}
\hline \multirow{2}{*}{ Osmotic characteristics } & \multicolumn{2}{|c|}{ Fresh slices } & \multicolumn{2}{c|}{ Steamed slices } \\
\cline { 3 - 6 } & \multicolumn{2}{|c|}{$\mathbf{6 0 \%}$} & \multicolumn{2}{c|}{$\mathbf{6 0 \%}$} \\
\cline { 3 - 6 } & $\mathbf{1 h r}$ & $\mathbf{2 h r s}$ & $\mathbf{1 h r}$ & $\mathbf{2 h r s}$ \\
\hline Weight reduction $\mathbf{( g / g )}$ & 0.227 & 0.349 & 0.403 & 0.502 \\
\hline Water loss $\mathbf{( g / g )}$ & 0.289 & 0.435 & 0.475 & 0.608 \\
\hline Solid gain $\mathbf{( g / g )}$ & 0.062 & 0.086 & 0.072 & 0.106 \\
\hline
\end{tabular}

Steaming process before OD as a pre-treatment for the fresh kiwifruit slices is affected on the aforementioned parameters. Where WR, WL and SG of not steamed kiwifruit slices dried by OD using $60 \%$ sucrose as $\mathrm{OS}$ at $40^{\circ} \mathrm{C}$ for $1 \mathrm{hrs}$ are $0.227,0.289$ and $0.062 \mathrm{~g} / \mathrm{g}$ increased 
in the steamed ones to $0.403,0.475$ and $0.072 \mathrm{~g} / \mathrm{g}$, respectively. The same trend is observed in the case of steamed kiwifruit slices after $2 \mathrm{hrs}$ of contact between the fruit and OS under the same conditions. These results could be explained by the cellular membrane of non-steamed kiwifruit exerts high resistances to mass transfer and slows down the rate of diffusion (Erule and Shubert, 2001), while steaming modify the cell structure by increase the membrane permeability to water and sugar exchanges (Del valle, et al., 1998; Kowalska, et al., 2008). Moreover, kiwifruit tissues have a porous structure so that steaming would also release the trapped air from the tissue resulting in more effective to the removal of water by osmotic pressure enhances the removal of water and uptake of solids (Phisut, 2012).

Dehydration efficiency index (DEI) is expressed by the ratio between water loss and solute gain $(\mathrm{WL} / \mathrm{SG})$. The DEI is depends strongly on the processing objectives and on the desired characteristics of the final product. In OD process, the higher water loss is more favourable than solid gain. Moreover, high solid gain affects negatively the quality and sensory characteristics of the dehydrated fruit. When high levels of sugar are infiltrated into the fruit during OD, significant sensory alterations can occur and the osmotically dehydrated product may present a different taste from the fresh fruit (Rodrigues and Fernandes, 2007). Therefore, good OD has DEI higher than 1 (Tylewicz, et al., 2010). The DEI of the dried kiwifruit slices is about 4.67 after $1 \mathrm{hrs}$ soaking in $60 \%$ OS at $40^{\circ} \mathrm{C}$, whichaugments to $5.08 \mathrm{~g} / \mathrm{g}$ after $2 \mathrm{hrs}$ (Fig. 1). It is obvious that as the immersion time in OS is extend, kiwifruit slices loss more water than that of SG. As a result DEI increases. These results are in agreement with those reported by Tylewicz, et al. (2010) and Fathi, et al. (2011a), who reported that DEI for Hayward kiwifruit slices dried by OD were increased by extend the contact time between kiwifruit and OS.

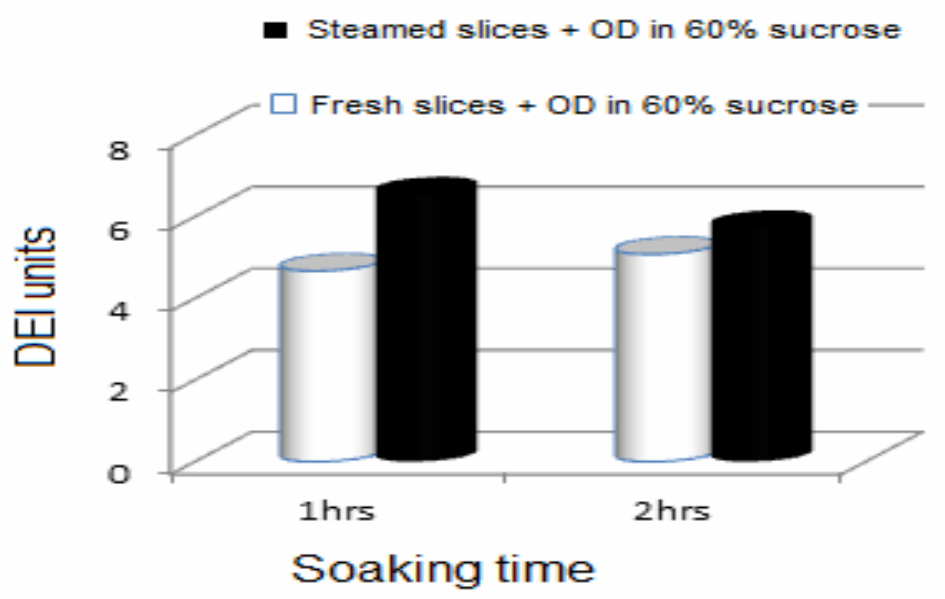

Fig.(1): Effect of OD at $40^{\circ} \mathrm{C}$ and steaming process on Dehydration efficiency index (DEI) in kiwifruit (Actinidiadeliciasa var. Hayward) slices. 
On the other hand, DEI of steamed kiwifruit slices decreased as the immersion period extends. This could be related to the change in the cell membrane of kiwifruit tissue by heating process. The dried kiwifruit samples, treated with steam before OD using OS $60 \%$ sucrose at $40^{\circ} \mathrm{C}$ for $1 \mathrm{hrs}$, had the greatest DEI 6.56 to 5.74 after $2 \mathrm{hrs}$. This could be related to steaming modify the cell structure by increase the membrane permeability to allow water to pass from the cell membrane rapidly (Del Valle, et al.,1998) and by a greater driving force due to OD. Therefore water is removed more at first and then moves slowly, while sugar penetration is very slight at first but increases with the time (Chavan, 2012).

2.2. Effect of steaming and OD on the hot air drying of kiwifruit slice

Table (2) summarized the effect of steaming and OD as pretreatments on mass loss (ML) and moisture content (MC) of dried kiwifruit slices by VHD. The results reveal that MC of fresh sample is decreases as the drying time is extend. At the meantime, ML increases.

Table 2. Effect of OD and steaming process as pre-treatment on drying Kiwifruit slices by ventilated hot-air oven drying (VHD) at $50^{\circ} \mathrm{C}$.

\begin{tabular}{|l|c|c|c|}
\hline \multicolumn{1}{|c|}{ Treatment } & $\begin{array}{c}\text { Time } \\
\text { (hrs) }\end{array}$ & $\begin{array}{c}\text { Moisture content } \\
\text { (MC \%) }\end{array}$ & $\begin{array}{c}\text { Mass 1oss } \\
\text { (ML \%) }\end{array}$ \\
\hline Fresh & ----- & $84.24^{\mathrm{a}} \pm 0.24$ & ------- \\
\hline \multirow{2}{*}{ Ventilated hot-air drying (VHD) } & 3 & $51.31^{\mathrm{b}} \pm 0.31$ & $55.07^{\mathrm{bc}} \pm 1.89$ \\
\cline { 2 - 4 } & 6 & $28.09^{\mathrm{f}} \pm 0.05$ & $79.74^{\mathrm{a}} \pm 1.06$ \\
\hline \multirow{2}{*}{ Steaming flowed by VHD } & 3 & $40.69^{\mathrm{c}} \pm 0.47$ & $60.45^{\mathrm{b}} \pm 0.85$ \\
\cline { 2 - 4 } & 6 & $25.14^{\mathrm{f}} \pm 0.13$ & $83.34^{\mathrm{a}} \pm 0.28$ \\
\hline \multirow{2}{*}{ OD in 60\% followed by VHD } & 3 & $44.69^{\mathrm{c}} \pm 0.41$ & $49.08^{\mathrm{c}} \pm 0.70$ \\
\cline { 2 - 4 } $\begin{array}{l}\text { Steaming, OD in 60\% followed } \\
\text { by VHD }\end{array}$ & 6 & $27.54^{\mathrm{f}} \pm 0.83$ & $59.56^{\mathrm{b}} \pm 1.31$ \\
\cline { 2 - 4 } & 3 & $34.83^{\mathrm{d}} \pm 0.72$ & $56.57^{\mathrm{b}} \pm 0.80$ \\
\hline LSD & & $24.49^{\mathrm{f}} \pm 0.32$ & $64.91^{\mathrm{a}} \pm 1.27$ \\
\hline
\end{tabular}

$\mathrm{M} \pm \mathrm{SD}=$ means and standard deviation of three successful trials

In a column, means have the same superscript letter are not significantly different at $0.05 \%$ level

Where MC of fresh kiwifruit slices is $84.24 \%$ decreases to $51.31 \%$ and $28.09 \%$ after 3 and 6 hrs of drying in VHD at $50^{\circ} \mathrm{C}$, respectively. But ML is $55.07 \%$ after 3 hrs increases to $79.74 \%$ after 6 hrs. This resultsimilarto those obtained by Chin et al.(2015), who reported that moisture of kiwifruit slices decreased with increasing of drying time, until it reached equilibrium status. As the kiwifruit slices exposed to steaming for $5 \mathrm{~min}$ before VHD, both MC and ML of the dried sample are changed. The MC deceases to $40.69 \%$ after $3 \mathrm{hrs}$ and $25.14 \%$ after $6 \mathrm{hrs}$. Also, ML is amplified to reach $60.45 \%$ and $83.34 \%$ for 3 and 6 hrs, respectively. These high values could be explained by 
the effect of heat on the cell wall of kiwifruit nature. Where, steaming process modifies or destruction the cell structure by loss the selective permeability. Therefore, the resistance to moisture diffusion decreases within the wall cell and water migrates to the surface of sample (Rocha, et al., 1993; Kowalska, et al., 2008). So, kiwifruit cells lost more water during VHD leading to decrease MC and increase ML. When the kiwifruit slices are exposed to OD by immersing in $60 \%$ sucrose of OS for $2 \mathrm{hrs}$ at $40^{\circ} \mathrm{C}$ before VHD, $\mathrm{MC}$ and ML are 44.69\% and 49.08\% after $3 \mathrm{hrs}$, respectively. Where MC decreased to $27.54 \%$ and ML increased to $59.56 \%$ after $6 \mathrm{hrs}$ of
VHD. The MC of kiwifruit slices steamed for $5 \mathrm{~min}$ and soaked in $60 \%$ OS for $2 \mathrm{hrs}$ at $40^{\circ} \mathrm{C}$ as pretreatment of VHD is $34.83 \%$ and $24.49 \%$ after 3 and $6 \mathrm{hrs}$, respectively. The corresponding values for ML are $56.57 \%$ and $64.91 \%$, respectively. This result agrees with Simal, et al. (1997) who reported that pretreatment of fruits in OS usually reduces the convective drying rates. Similar results were reported in the literature (Karim, et al., 2008; Karim, 2010) for steamed sample exposed to OD followed by VHD. It is clear that effect of steaming is more pronouncing on the permeability of cell walls in the kiwifruit slices rather than OD.

Table 3. Effect of different treatment on rehydration capacity (RC) of dried kiwifruit slices

\begin{tabular}{|l|c|c|c|c|}
\hline \multirow{2}{*}{ Treatment } & \multicolumn{4}{c|}{ Rehydration ratio (RR) } \\
\cline { 2 - 5 } & $15 \mathrm{~min}$ & $30 \mathrm{~min}$ & $45 \mathrm{~min}$ & $60 \mathrm{~min}$ \\
\hline Ventilated hot air drying (VHD) & $5.05^{\mathrm{c}} \pm 0.33$ & $10.54^{\mathrm{c}} \pm 0.69$ & $13.84^{\mathrm{b}} \pm 0.31$ & $18.29^{\mathrm{b}} \pm 0.39$ \\
\hline Steaming flowed by VHD & $9.32^{\mathrm{b}} \pm 0.21$ & $11.47^{\mathrm{c}} \pm 0.24$ & $18.32^{\mathrm{b}} \pm 1.19$ & $21.23^{\mathrm{b}} \pm 1.40$ \\
\hline OD in 60\% followed by VHD & $22.50^{\mathrm{a}} \pm 1.24$ & $26.48^{\mathrm{a}} \pm 1.41$ & $45.42^{\mathrm{a}} \pm 2.24$ & $47.61^{\mathrm{a}} \pm 2.33$ \\
\hline $\begin{array}{l}\text { Steaming, OD in 60\% followed } \\
\text { by VHD }\end{array}$ & $9.68^{\mathrm{b}} \pm 0.42$ & $20.28^{\mathrm{b}} \pm 0.93$ & $36.02^{\mathrm{a}} \pm 1.95$ & $41.85^{\mathrm{a}} \pm 2.26$ \\
\hline LSD & 3.21 & 5.31 & 11.33 & 14.63 \\
\hline
\end{tabular}

$\mathrm{M} \pm \mathrm{SD}=$ means and standard deviation of three successful trials

In a column, means have the same superscript letter are not significantly different at $0.05 \%$ level

\subsection{Rehydration Capacity (RC)}

Dehydrated products often need to be rehydrated for utilization, where rehydration capacity (RC) is an important index of the quality of dried fruits (Aversa et al., 2012). Safety, nutritional and sensory aspects of foods is usually related to the rehydration process as well as to the severity of the drying practice
(Marabi and Saguy, 2009). Thus, rehydration can be considered as a measure of the damage to the product caused by dehydration since RC is related to modifications in food structure during processing (GarciaPascual, et al., 2006; Moreira, et al., 2008). Rehydration of dried food tissues is composed of three simultaneous processes: 1) the imbibition of 
water into dried material, 2) the swelling of the rehydrated products, and 3 ) the leaching of soluble solids to rehydration medium (Krokida and Marinos-Kouris, 2003). Poor rehydration caused by injuries to the plant tissue cells during pretreatment and drying (Lewicki, 1998). So, good dehydration process has high RC. The RC of dehydrated samples after 15, 30, 45 and $60 \mathrm{~min}$ are shown in Table (3). The RC for kiwifruit slices dried by VHD is $5.05,10.54,13.84$ and 18.29 after $15,30,45$ and $60 \mathrm{~min}$ of rehydration in distilled water at room temperature, respectively. The same trend is noticed also for dried kiwifruit slices dried by VHD after steaming or OD in $60 \%$ sucrose and steaming followed by OD in $60 \%$ sucrose. However, the method of dehydration has an obvious effect on the RC, whereas kiwifruit slices dehydrated by OD in $60 \%$ sucrose as pre-treatment followed by VHD, which has the significantly $(p>0.05)$ highest RC among the other studied dehydration methods. On the other hand, RC of steamed samples is not significantly ( $p>0.05$ ) different than that of control. It is well known that poor rehydration capacity could be attributing to the collapse of cellular structure or the decrease of porosity lead to lower diffusion of water into kiwifruit tissue during rehydration. Similar trend was reported by Singh, et al.(2008 a) and Fathi, et al.(2011b) for rehydration capacity of chestnut and kiwifruit during hot air drying, respectively. These results are disagreement with Kaymak-Ertekin, 2002; Taiwo and Adeyemi, 2009) who showed that blanching didn't had any significant $(p>0.05)$ effect on the RC of the samples irrespective of the drying temperature. Fig. 2 shows the fresh, dried and rehydrated (after one hour) kiwifruit slices as affected by different drying methods.

The RC of kiwifruit slices exposed to OD before VHD had the highest significantly $(p>0.05)$ value among other studied treatments along the different rehydration time. The high $\mathrm{RC} \%$ of ODkiwifruits slices may be explained by the pretreated sample with OD had high percentage of sugar which leaches out into the rehydration solution and uptake more water amount due to the different solute concentration between the two sides of the cell membrane. This is conflicted with Singh et al.(2007) who reported that the $\mathrm{RC}$ is high for un-osmosed samples and lowest for the osmotically pretreated carrot cubes with sucrose-salt mixture as OS.

However, results of Bhuvaneswari et al.(1999) supported our findings, who reported that RC of osmotically treated peas was higher than those of untreated samples. All the samples exhibited an initial high rate of moisture sorption and solute loss followed by slower water absorption and solute loss in the later stages of rehydration process. This is due to the fact that the capillary imbibitions are important at early stages, which leads to an almost instantaneous uptake of water. Similar results were reported by Sopade and Obekpa (1990).

\section{Conclusion}

In conclusion, OD as pretreatment process followed by VHD 
an effective method which gives the best result for drying Kiwifruit slices. Since, RC of this treatment is the superior treatment. While steamed sample followed by OD be-
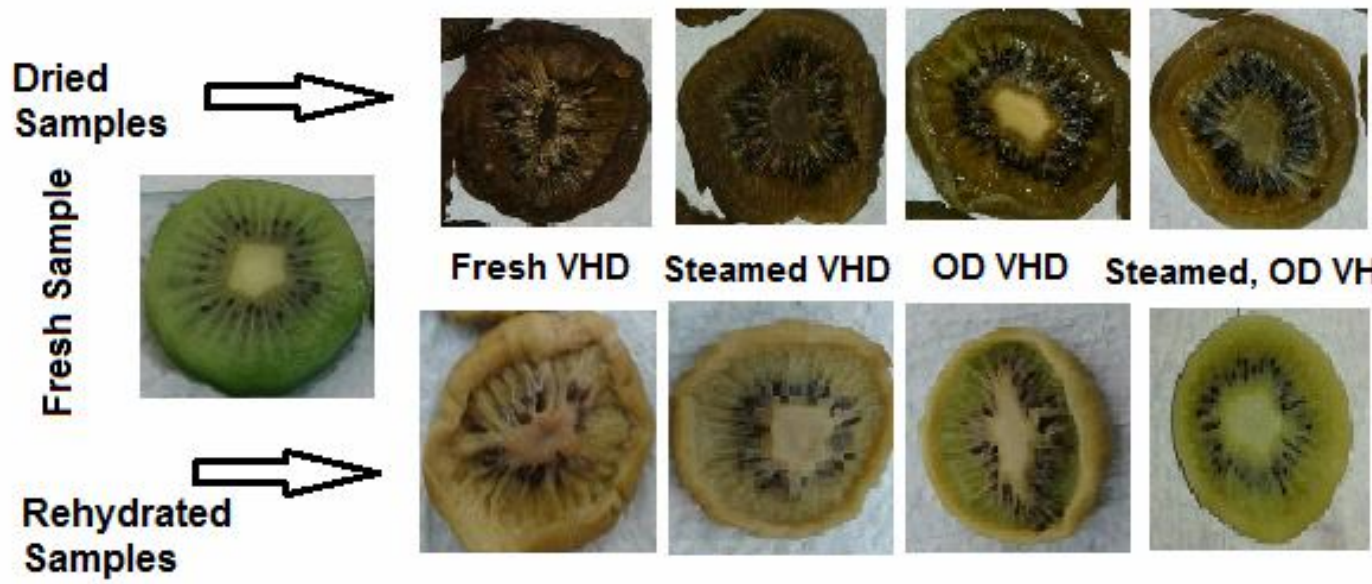

Fresh VHD Steamed VHD
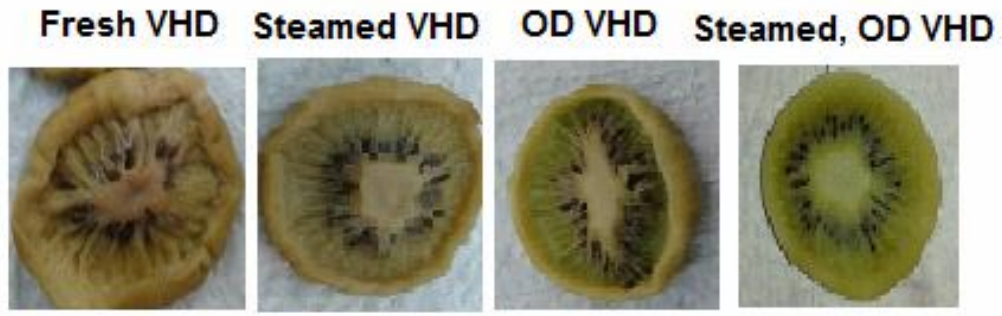

Fig. (2): Dried and rehydrated (after one hour) kiwifruit slices as affected by different methods of rehydration process

\section{Reference}

Abano, EE and Sam-Amoah, LK (2011). Effects of different pretreatments on drying characteristics of banana slices. Journal of Engineering and AppliedSciences, 6 (3): 121-129.

Allaeddini, B and Emam-Djomeh, Z (2004). Formulation and quality improvement of dried kiwifruit slices using an osmotic pretreatment. Drying 2004 - Proceedings of the $14^{\text {th }}$ International Drying Symposium (IDS 2004) Sao Paulo, Brazil, 22-25 August 2004, p: 2127-2132.

Allali, H; Marchal, L and Vorobiev, E (2010). Blanching of strawberries by ohmic heating: Effects on the kinetics of mass transfer during osmotic dehydration. Food Bioprocess Technology, 3: 406-414.

Amami,E; Vorobiev, E and Kechaou, N (2006). Modelling of mass transfer during osmotic dehydration of apple tissuepre-treated by pulsed electric field. LWT-Food Science and Technology, 39: 1014-1021.

AOAC (2003). Official Methods of Analysis $17^{\text {th }}$ (ed) Association of Official Analytical Chemists, Virginia, USA.

Aversa, M; Curcio, S; Calabrò, V and Iorio, G (2012). Experimental evaluation of quality parameters during drying of carrot samples.Food and Bioprocess Technology, 5(1):118-129.

Bchir, B;Besbes,S;Attia,HandBlecker,C (2011). Osmotic dehydration of pomegranate seeds (PunicaGranatum L.): Effect offreezingpre-treatment. Journal of Food Process Engineering, 35(3):335 354.

Bekele, Y and Ramaswamy, H (2010). Going beyond conventional osmotic dehydration for quality advantage and energy savings. Elhiopian Journal of Applied Sciences and Technology, 1(1): 1-15.

Bhuvaneswari, SV; Sreenaryanan, V; Kailappan, $\mathrm{R}$ and Parvathy, $\mathrm{K}$ 
(1999). Osmotic dehydration of peas.Indian Food Packer, 53: 1012.

Cao, H; Zhang, M; Mujumdar, AS; Du,W and Sun, J (2006). Optimization of osmotic dehydration of Kiwifruit. Drying Technology, 24 (1): 89-94.

Cassano, A; Figoli, A;Tagarelli, A; Sindona, G and Drioli, E (2006). Integrated membrane process for the production of highly nutritional kiwi fruit juice. Desalination, 189: 21-30.

Chavan, UD (2012). Osmotic dehydration process for preservation of fruits and vegetables. Journal of Food Research, 1(2):202- 209.

Chin, SK; Siew, ES and Soon, WL (2015). Drying characteristics and quality evaluation of kiwi slices under hot air natural convective drying method. International Food Research Journal, 22(6): 2188-2195.

Del Valle, MJ; Aranguiz, V and Leon, $\mathrm{H}$ (1998). Effect of blanching and calcium infiltration on PPO activity, texture, microstructure and kinetics of osmotic dehydration of apple tissue.Food Research International, 31: 557-569.

Diamante, L; Durand, M; Savage, G and Vanhanen, L (2010). Effect of temperature on the drying characteristics, colour, ascorbic acid content of green and gold kiwifruits. International Journal of Food Research, 17: 441-451.

Erule, U and Schubert, H (2001) Combined osmotic and microwavevacuum dehydration of apples and strawberries. Journal of Food Engineering, 49:193-199.

Escriche, I; Chiralt, A; Moreno, J and Serra, JA (2000a). Influence of blanching - osmotic dehydration treatments on volatile fraction of
Strawberries. Journal of FoodScience, 65:1107-1111.

Escriche, I; García-Pinchi, R; Andrés, A and Fito, P (2000b). Osmotic dehydration of kiwi fruit (Actinidiachinensis): Fluxes and mass transfer kinetics. Journal of Food Process Engineering, 23 (3):191205.

Etsey, AN; Sakyi-Dawson, E; SefaDedeh, S; Afoakwa, EO; TanoDebrah, K and Annor,GA (2007). Effects of cowpea fortification and the level of ripeness of plantain on the nutritive value of plantain based snack foods. African Journal of Biotechnology, 6(6): 799-802.

FAO (2010). Food and Agriculture Organisation, available in the Internet at: http://faostat.fao.org/ faostat $/$ form?collection $=$ Production.Crops.Primary\&Domain=Pro duction\&servlet $=1 \&$ hasbulk $=0$ \&version $=$ ext\&language $=\mathrm{EN}$.

Fasogbon, BM; Gbadamosi, SO and Taiwo, KA(2013). Studies on the osmotic dehydration and rehydration characteristics of Pineapple slices.Food Processing and Technology, 4(4):220 - 227.

Fathi, M; Mohebbi, $M$ and Razavi, SMA (2011a).Application of image analysis and artificial neural network to predict mass transfer kinetics and color changes of osmotically dehydrated kiwifruit. Food Bioprocess Technology, 4(8): 1357-1366.

Fathi, M; Mohebbi, M andRazavi, SMA (2011b). Effect of osmotic dehydration and air drying on physicochemical properties of dried kiwifruit and modelling of dehydration process using neural network and genetic algorithm. Food Bioprocess Technology, 4:1519-1526.

Fazli, FA and Ahani, M (2010). Minimally processed foods: A case 
study on orange and kiwi fruit. International Journal of Environmental Science and Development, $1(1): 53-56$.

Ferguson, AR (1990). Botanical Nomenclature: Actinidiachinensis, Actinidiadeliciosa and Actinidiasetosa. In: Warrington, IJ and Weston, GC (Eds.) Kiwifruit: Science and Management, Ray Richards Publisher in Association with the new Zealand Society for Horticultural Science, Auckland, New Zealand, PP: 36-57.

Fito, P; Chiralt, A; Barat, JM; Andres, a; Martinez-Monzo, J and Martinez-Navarrete, N (2001). Vacuum impregnation for development of new dehydrated products.Journal of Food Engineering, 49: 297302.

Garcia-Pascual, P; Sanjuan, N; Melis, R and Mulet, A (2006). Morchellaesculenta (morel) rehydration process modeling. Journal of Food Engineering, 72(4): 346353.

Gianotti, A; Sacchetti, G; Guerzoni, ME and Dalla, Rosa M (2001). Microbial aspects on short-time osmotic treatment of kiwifruit. Journal of Food Engineering, 49: 265-270.

Hosseinzadeh, J; Feyzollahzadeh, M and Afkari, AH (2013). The physical and chemical properties of kiwifruit harvested at four stages. Bulgarian Journal of Agricultural Science, 19 (1) 174-180.

Karim, OR (2010). Air-oven drying of pre-treated fruit slices: A promising solution to post-harvest losses. Pakistan Journal of Nutrition, 9 (6): 547-551.

Karim, OR; Awonorin, SO and Sanni, LO (2008). Effect of pretreatments on quality attributes of air-dehydrated pineapple slices. Journal of Food Technology, 6 (4): 158-165.
Kaymak-Ertekin, F(2002). Drying and rehydrating kinetics of green and red peppers. Journal of Food Science, 67(1): 168-175.

Kowalska, H; Lenart, A and Leszczyk, D (2008). The effect of blanching and freezing on osmotic dehydration of pumpkin. Journal of Food Eng., 86: 30-38.

Krokida, MK and Marinos-Kouris, D (2003). Rehydration kinetics of dehydrated products. Journal of Food Eng., 57(1): 1-7.

Latapi, G and Barrett, M (2006). Influence of pre-drying treatments on quality and safety of sun-dried tomatoes. Part I: Use of steam blanching, boiling brine blanching, and dips in salt or sodium metabisulfite. Journal of Food Sci., 71: 24-31.

Lewicki, PP (1998). Some remarks on rehydration of dried foods. Journal of Food Engineering, 36:8187.

Lewicki, PP (2006). Design of hot air drying for better food. Trends in Food Science and Technology, 17: 153-163.

Llanoa, KM; Haedob, AS; Gerschensona, LN and Rojasa, AM (2003). Mechanical and biochemical response of kiwifruit tissue to steam blanching.Food Research International, 36: 767-775.

Marabi, A and Saguy, IS (2009). Rehydration and reconstitution of foods. In:Ratti, C (Ed.), Advances in food dehydration. Boca Raton: Chemical Rubber Company CRC Press, USA.

Marani, CM; Agnelli, ME and Mascheroni, RH (2007). Osmofrozen fruits: mass transfer and quality evaluation. Journal of Food Engineering, 79:1122-1130.

Maskan, M (2000). Microwave/air and microwave finish drying of ba- 
nana. Journal of Food Engineering, 44(2): 71-78.

Maskan, M (2001). Drying, shrinkage and rehydration characteristics of Kiwi fruits during hot air and microwave drying. Journal of Food Engineering, 48: 177-182.

Mavroudis, NM; Gekas, V and Sjoholm, I (1998). Osmotic dehydration of apples effect of agitation and row material characteristics .Journal of Food Engineering, 35: 191-209.

Menges, HO and Ertekin, C (2006). Mathematical modelling of thin layer drying of Golden apples. Journal of Food Engineering, 77: 119-125.

Moreira, R and Sereno, AM (2003). Evaluation of mass transfer coefficients and volumetric shrinkage during osmotic dehydration of apple using sucrose solution in static and non-static conditions. Journal of food engineering, 57:25-31.

Moreira, R; Chelco, F; Chaguri, L and Fernandes, C (2008). Water absorption, texture, and color kinetics of air-dried chestnuts during rehydration. Journal of Food Engineering, 86(4): 584-594.

Nadian, MH; Abbaspour-Fard, MH; Sadrnia, H; Golzarian, MR and Tabasizadeh, M (2016). Optimal pretreatment determination of kiwifruitdrying via online monitoring .Journal of science food Agriculture, 96:4785 - 4796.

Nieuwenhuijzen, NH; Zareifard, MR and Ramaswamy, HS (2001). Osmotic drying kinetics of cylindrical apple slices of different sizes.Drying Technology, 19 (34): 525-545.

Osorio,C; Franco, MS; Castaño, MP; González-Miret, ML; Heredia, FJ and Morales, AL (2007). Colour and flavour changes during osmotic dehydration of fruits. Jour- nal of Innovative Food Science and Emerging Technologies, 8: $353-359$.

Phisut, N (2012). Factors affecting mass transfer during osmotic dehydration of fruits. Journal of international Food research, 19 (1): 718.

Reynolds, Susan MS (2007). Drying Fruits. Available on the Internet at: http://www.edis.ufl.edu.

Robbers, M; Singh, RP and Cunha, LM (1997). Osmotic-convective dehydro -freezing process for drying kiwifruit. Journal of Food Sci., 62(5):1039-1047.

Rocha, T; Lebert, A; Marty-Audouin, C(1993). Effect of pretreatments and drying conditions on drying rate and colour retention of basil (Ocimumbasilicum), LebensmittelWissenschaft und Technologie, 26: 456-463.

Rodrigues, $\mathrm{S}$ and Fernandes, FAN (2007). Image analysis of osmotically dehydrated fruits: Melons dehydration in a ternary system. European Food Research and Technology, 225: 685-691.

SAS 2004 SAS Institute Inc (2004). SAS User"s Guide, Version 9.1 Statically Analysis System Institute, Cary, NT.

Senadeera, W; Bhandari, BR; Young, G and Wijesinghe, B (2005). Modelling dimensional shrinkage of shaped foods in fluidized bed drying. Journal Food Processing and Preservation, 29: 109-119.

Shi, J and Xue JS (2009). Application and development of osmotic dehydration technology in food processing . In: Ratti, C (Ed.) Advances in Food Dehydration. Chemical Rubber Company CRC Press, USA.

Simal, S; Deya, E; Frau, M; Rossello, C (1997). Simple Modelling of air drying curves of fresh and osmo- 
tically pre-dehydrated apple cubes. Journal of Food Engineering, 33(1-2):139-150.

Singh, GD; Sharma, R; Bawa, AS; and Saxena, DC(2008a). Drying and rehydration characteristics of water chestnut Trapanatans as a function of drying air temperature. Journal of Food Engineering, 87, 213-221.

Singh, S B; Panesar, $\mathrm{P}$ and Nanda, V (2007). Rehydration kinetics of un-osmosed and pre-osmosed Carrot cubes. World Journal of Dairy and Food Sci., 2 (1):10-17.

Singh, U; Jain, SK; Doshi, A; Jain, KH and Chahar, KV (2008b). Effects of Pretreatments on Drying Characteristics of Button Mushroom. International Journal of Food Engineering, the Berkeley Electronic Press, California University.4 (4): 1556-3758.

Sopade, PA and Obekpa, JA (1990). Modeling water absorption in soyabean, cowpea and peanuts at three temperatures using Peleg's
equation.Journal of Food Science, 55: 1084-1087.

Sun, DW (2005). Emerging Technologies for Food Processing. London: Academic Press, Elsevier Science, pp.221- 223.

Taiwo, KA and Adeyemi, O (2009). Influence of blanching on the drying and rehydration of banana slices. African Journal of Food Science, 3(10):307-315.

Torreggiani, D and Bertolo, G (2001). Osmotic pre-treatments in fruit processing: Chemical, physical and structural effects. Journal of Food Engineering, 49: 247-253.

Tortoe, C (2010). A review of osmodehydration for food industry. African Journal of Food Science, 4(6): $303-324$.

Tylewicz,U; Rząca, M; Rocculi, P; Romani, S and Dalla Rosa, M(2010). Evolution of quality characteristics of Hayward and Hort16A kiwifruit during osmotic dehydration. Journal of fruit processing, 4: 150-153. 
تأثير التجفيف الاسموزى كمعامله مبائيه على بعض خصائص شرائح فاكهة الكيوى المجفقة بفرن التهوية بالهواء باء الساخن

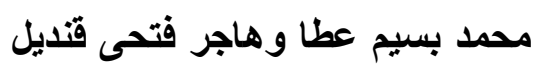

قسم علوم وتكنولوجيا الاغذيه - كلية الزر اعة - جامعة طنطا

(الملخص

يعتبر تجفيف الأغذيه خاصة الفواكة إحدى العمليات الأكثز تحديا فى تكنولوجيا الأغذيــه. ولكى نحسن من جوده الفو اكه المجففه ينبخى أن نطور أساليب التجفيف التقليدية لطرق جديــده. حيث أن مجفات الهو اء الساخن تتتج فو اكه مجففه ذات جوده رديئة لذلك طبقت أساليب مختلفــة لتقليل عيوب الطرق التقليدية. من أجل ذلك تمت در اسة تجفيف شر ائح فاكهة الكيوي المعرضـــه للبخار و التجفيف الأسموزى (OD) فى محلول سكروز ، \% كمعامله مبئيه متبو عه بـالتجفيف بالهو اء الساخن(VHD) )

أوضحت النتائج أن الفقد في كل من الوزن (ML) و الرطوبـــة (WL) وكــللك المـــواد الصلبه المكتسبه (SG) لشر ائح الكيوى تزداد معنويا بزياده وقت الغمر في المحلـــول الـسكري. وكان الفقد في الوزن (ML) أقل من فقد الرطوبة (WL) خلال التجفيـف الاســوزى (OD). ولوحظ أن الفقد في الرطوبة (WL) كان أعلى من أكتساب المــواد الــصلبه (SG). كــل مــن

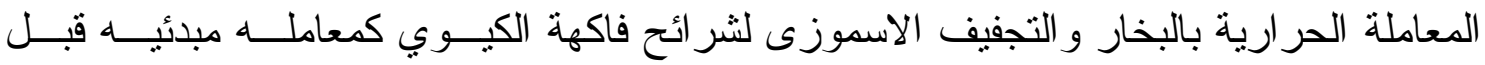
التجفيف بالهو اء الساخن في الفرن يزيد من نفاذية أغثيه الخلايا و تميزت المعاملـــة الحر اريـــة بقرتها علي طرد الهو اء المحبوس بين أنسجة الفاكهة مما ادي الي زيادة الفقد في الوزن(ML) و النسبة المئوية للرطوبة (MC\%) .، و ارتفاع مؤشر كفاعة التجفيف (DEI) في المنتج النهـائي

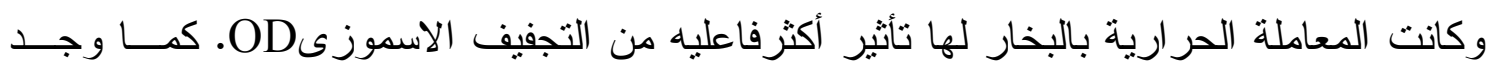
تحسن في خاصيه إعادة التشرب (RC) لثرائح فاكهة الكيــوي المجفقـة بو اســـة التجفيــف

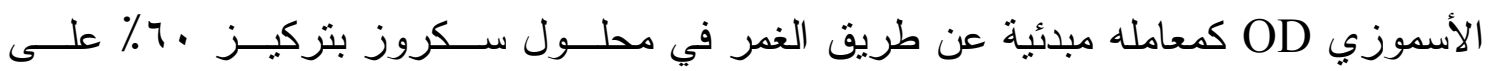
درجة • عم ه لمدة ساعتين لها تأثنر إيجابي علي شر ائح فاكهة الكيوي المجففة بينما عملية المعاملة الحر اريةبالبخار ليس له تأثير ملحوظ. 